\title{
A nonsense mutation in the tyrosinase gene causes albinism in water buffalo
}

\author{
Maria Cecília Florisbal Damé ${ }^{\prime}$ Gildenor Medeiros Xavier ${ }^{2}$, José Paes Oliveira-Filho ${ }^{3}$, Alexandre Secorun Borges ${ }^{4 *}$, \\ Henrique Nunes Oliveira ${ }^{5}$, Franklin Riet-Correa ${ }^{6}$ and Ana Lucia Schild ${ }^{7}$
}

\begin{abstract}
Background: Oculocutaneous albinism (OCA) is an autosomal recessive hereditary pigmentation disorder affecting humans and several other animal species. Oculocutaneous albinism was studied in a herd of Murrah buffalo to determine the clinical presentation and genetic basis of albinism in this species.

Results: Clinical examinations and pedigree analysis were performed in an affected herd, and wild-type and OCA tyrosinase mRNA sequences were obtained. The main clinical findings were photophobia and a lack of pigmentation of the hair, skin, horns, hooves, mucosa, and iris. The results of segregation analysis suggest that this disease is acquired through recessive inheritance. In the OCA buffalo, a single-base substitution was detected at nucleotide 1,431 (G to A), which leads to the conversion of tryptophan into a stop codon at residue 477.

Conclusion: This premature stop codon produces an inactive protein, which is responsible for the OCA buffalo phenotype. These findings will be useful for future studies of albinism in buffalo and as a possible model to study diseases caused by a premature stop codon.
\end{abstract}

Keywords: Albinism, Buffalo, Nonsense mutation, Stop codon, Tyrosinase

\section{Background}

Oculocutaneous albinism (OCA) is an autosomal recessive hereditary disorder characterized by a partial or total absence of melanin in the hair, skin and eyes in humans and animals. Tyrosinase catalyzes the first two steps of melanin biosynthesis, i.e., the hydroxylation of tyrosine to 3, 4-dihydroxyphenylalanine (DOPA) and the subsequent oxidation of DOPA to dopaquinone [1]. Loss of tyrosinase (TYR) mRNA expression prevents melanin synthesis, thereby causing albinism [2].

Cases of OCA caused by mutations in the TYR gene that encodes tyrosinase have been documented in several mammalian species, including humans [2-8]. Mutations in other genes (TYRP1, OCA2) have also been associated with different types of OCA [9-11] and ocular albinism (OA1) in humans [12]. Mutations in the human LYST and HPS genes are responsible for OCA and are associated with Chediak-Higashi [13] and Hermansky-Pudlak

\footnotetext{
* Correspondence: asborges@fmvz.unesp.br

${ }^{4}$ Laboratory of Molecular Biology of Department of Veterinary Clinical Science / College of Veterinary Medicine and Animal Science, Univ Estadual Paulista (Unesp), Botucatu, Sao Paulo 18618-970, Brazil

Full list of author information is available at the end of the article
}

[14] syndromes, respectively. Mutation of the LYST gene in cattle is also responsible for OCA and for a syndrome similar to the human form of Chediak-Higashi [15].

Oculocutaneous albinism has previously been reported in an Anatolian buffalo calf in Turkey [16] and in a herd of Murrah buffalo in Brazil [17]. Additionally, a white water buffalo calf was described in 1925 [18] in which every hair on the body was white but the eyes exhibited normal pigmentation. However, the mutation responsible for these cases was not investigated. The objective of the present study is to report the clinical and genetic features of albinism in a herd of water buffalo of the Murrah breed. We report the sequence of the TYR gene in both wild-type and OCA Murrah buffalo and describe a nonsense mutation that produces a premature stop codon that results in an abbreviated protein product. This abnormal protein is responsible for OCA in these animals.

\section{Methods \\ Epidemiology and clinical signs}

The disease was studied in a herd of Murrah buffalo in the state of Rio Grande do Sul in southern Brazil

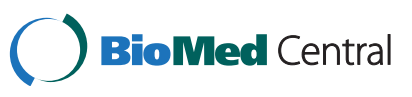


(S $31^{\circ} 49^{\prime} 03^{\prime \prime}$ and W $52^{\circ} 26^{\prime} 25^{\prime \prime}$ ). The data were obtained by reviewing the genetic records of the experimental herd (1297 animals born into the herd beginning in 1996), and the affected buffalo were subjected to clinical examination. The active sires in 1996 were considered as a base population to the estimate herd's consanguinity. However, the complete genealogical data from these sires and from those sires incorporated into the herd after 1996 were used for segregation analysis. The segregation analysis and the estimation of allele frequencies were performed using Geneprob software (Gene Probe Inc., Atlanta, GA) [19]. The coefficient of consanguinity was calculated using in-house-developed software based on the algorithm described by Meuwissen and Luo [20]. Under a hypothesis of Mendelian recessive inheritance with complete penetrance, the frequency of albinism among offspring that were from sires considered to be unequivocally heterozygous and were mated either with their own daughters or with daughters from sires sharing the same characteristics was tested to determine if the observed frequency of albinism agreed with the expected frequency, considering a binomial distribution ( $\mathrm{n}, \mathrm{p}=1 / 8)$.

\section{Animals}

All experiments were performed according to the regulations of the Sao Paulo State University Institutional Animal Care and Use Committee (231/2011-CEUA). Skin samples were collected from six Murrah buffalo with a clinical diagnosis of OCA (III-110, VII-690, X-253, X257, X-273, and XII-10a) and from four normal Murrah buffalo with black skin (control group). The TYR mRNA sequence was then determined for each subject. The animals used as the control group belonged to a herd from Sao Paulo State (S 22 $2^{\circ} 8^{\prime} 78^{\prime \prime}$ and W 48 50'07”). Blood samples for single nucleotide polymorphism (SNP) DNA sequencing were collected from 15 Murrah buffalo, including nine albinos (III-110, VII-690, IX-167, X-253, X-257, X-273, XI-290, XI-351, and XII-10a), four heterozygotes (VI-523, VI-639, VIII-7, and VIII-553) and two wild-type buffalo (control herd).

\section{Tyrosinase mRNA sequencing in the normal buffalo}

Skin biopsies were obtained from four black wild-type buffalo using a 5-mm punch (Kolplast, Sao Paulo, Brazil). The samples were frozen in liquid nitrogen immediately after the biopsy procedure and then stored at $-80^{\circ} \mathrm{C}$ until RNA purification. Total RNA was isolated from the skin samples using the RNeasy ${ }^{\circledR}$ Mini Kit (Qiagen ${ }^{\circledR}$, Valencia, CA) according to the manufacturer's instructions. The relative purity and quality of the isolated RNA were determined with a Nanodrop ${ }^{\circledR} 2000$ Spectrophotometer (Thermo Scientific ${ }^{\mathrm{TM}}$, Wilmington, DE). The absorbance ratio (A260/A280 nm) exceeded 1.8 for all samples. To ensure the complete removal of all genomic DNA, $2 \mu \mathrm{g}$ of total RNA was incubated with RQ1 RNase-Free DNase (Promega, Madison, WI) according to the manufacturer's instructions. First-strand cDNA synthesis was performed using $600 \mathrm{ng}$ of total RNA per $60 \mathrm{ml}$ reaction volume using random hexamers and the ImProm-II ${ }^{\mathrm{TM}}$ Reverse Transcription System (Promega) according to the manufacturer's instructions.

Because the buffalo TYR mRNA sequence is not publicly available, 10 sets of heterologous primers were designed (Table 1) based on the Bos taurus TYR mRNA sequence deposited in GenBank ${ }^{\mathrm{TM}}$ (NM_181001.2). PrimerQuest ${ }^{\circledR}$ software (Integrated DNA Technologies Inc., Coralville, IA) was used to obtain the TYR mRNA sequence of the normal buffalo.

The RT-PCR amplifications were performed in a total volume of $50 \mu \mathrm{l}$, which contained $0.3 \mu \mathrm{M}$ each forward and reverse primer, $5 \mu \mathrm{l}$ of template cDNA, $25 \mu \mathrm{l}$ of GoTaq $^{\circledR}$ Green PCR Master Mix (Promega), and $17 \mu \mathrm{l}$ of nuclease-free water. In addition, a no-template control reaction was performed in duplicate to check for the possible presence of contamination in the preparations. The obtained RT-PCR products were analyzed via $1.5 \%$ agarose gel electrophoresis (Invitrogen ${ }^{\mathrm{TM}}$, Carlsbad, CA), stained with the Sybr ${ }^{\circledR}$ Safe DNA Gel Stain (Invitrogen $^{\mathrm{TM}}$ ) and then purified using the QIAquick ${ }^{\circledR}$ PCR Purification Kit $\left(\right.$ Qiagen $\left.{ }^{\circledR}\right)$. The purified products of the correct estimated size were then submitted for direct sequence analysis using BigDye ${ }^{\circledR}$ Terminator v3.1 Cycle Sequencing (Applied Biosystems ${ }^{\mathrm{TM}}$, Foster City, CA). Each reaction was performed in quadruplicate using $5 \mu \mathrm{l}$ of each of the forward and reverse primers and $10 \mu \mathrm{l}$ of the RT-PCR product. The obtained sequences and electropherograms were analyzed using Sequencing Analysis 5.3.1 software (Applied Biosystems ${ }^{\mathrm{TM}}$ ). The B. bubalis TYR mRNA sequence obtained from wild-type buffalo was subjected to BLAST searches (http://blast.ncbi.nlm. nih.gov) against other mammalian TYR sequences deposited in GenBank ${ }^{\mathrm{TM}}$ and aligned using CLUSTAL X software.

\section{Tyrosinase mRNA sequencing of buffalo with OCA}

Skin biopsies were performed on the six buffalo with OCA, and RNA purification, reverse transcription, RTPCR and sequencing were performed as described above to obtain the TYR mRNA sequences. These sequences were then compared to the wild-type B. bubalis TYR mRNA sequence using the CLUSTAL $X$ program to identify potential mutations in the TYR mRNA sequence from the buffalo with OCA.

\section{Single nucleotide polymorphism (SNP) DNA sequencing} Blood sample DNA purification was performed using an Ilustra $^{\mathrm{TM}}$ blood genomic Prep Mini Spin Kit (GE Healthcare Life Science, Buckinghamshire, UK) according to 
Table 1 Primers used for RT-PCR amplification of B. bubalis tyrosinase mRNA

\begin{tabular}{|c|c|c|c|c|}
\hline & Name & Primer Sequence $\left(5^{\prime}-3^{\prime}\right)$ & Product Size (bp) & Annealing Temperature \\
\hline \multirow[t]{2}{*}{1} & ASB.TYR - F1 & TGAAAGGGAAGAGTGTGGCTCCAT & 411 & $60^{\circ} \mathrm{C}$ \\
\hline & ASB.TYR - R8 & TCGCCTTTCTGTGCAGCGGG & & \\
\hline \multirow[t]{2}{*}{2} & JP.TYR - F2 & AGTCTTGGCCCTCCATCTIT & 350 & $60^{\circ} \mathrm{C}$ \\
\hline & JP.TYR - R2 & GACTTCAGAGTCCCCAAGCA & & \\
\hline \multirow[t]{2}{*}{3} & ASB.TYR - F6 & TCCCCACGGGCACCTATGGC & 419 & $60^{\circ} \mathrm{C}$ \\
\hline & ASB.TYR - R1 & GTTGCATAAAGCCTGGCGACTGTT & & \\
\hline \multirow[t]{2}{*}{4} & ASB.TYR - F7 & CATGGGAGGGCGCAACCCTG & 533 & $60^{\circ} \mathrm{C}$ \\
\hline & ASB.TYR - R2 & AAGGAACCATGTAGGATTCCCGGT & & \\
\hline \multirow[t]{2}{*}{5} & ASB.TYR - F2 & AACAGTCGCCAGGCTITATGCAAC & 439 & $60^{\circ} \mathrm{C}$ \\
\hline & ASB.TYR - R2 & AAGGAACCATGTAGGATTCCCGGT & & \\
\hline \multirow[t]{2}{*}{6} & JP.TYR - F4 & GATCTGCCAATGATCCCATC & 329 & $60^{\circ} \mathrm{C}$ \\
\hline & JP.TYR - R4 & AAGGACAGACCCAACCACAG & & \\
\hline \multirow[t]{2}{*}{7} & ASB.TYR - F3 & TAGAACAAGCACAACGAATCTGGC & 377 & $60^{\circ} \mathrm{C}$ \\
\hline & ASB.TYR - R3 & AAAGCAAGCACAGGTGGCTTCTAC & & \\
\hline \multirow[t]{2}{*}{8} & ASB.TYR - F4 & ACCGGGAATCCTACATGGTTCCTT & 225 & $60^{\circ} \mathrm{C}$ \\
\hline & ASB.TYR - R4 & TAAGTCCTCCCAGCACAGCAGTAA & & \\
\hline \multirow[t]{2}{*}{9} & ASB.TYR - F5 & AATGTAGCCCTCCTCCTACTCAGGTA & 215 & $60^{\circ} \mathrm{C}$ \\
\hline & ASB.TYR - R5 & GGGAACAAGTCATTCCACAATCAAGAGG & & \\
\hline \multirow[t]{2}{*}{10} & JP.TYR - F6 & CAATAGAGCTGGGGCAAAAA & 247 & $60^{\circ} \mathrm{C}$ \\
\hline & JP.TYR - R6 & TACCAAATGGCATCCTTTCC & & \\
\hline
\end{tabular}

the manufacturer's instructions. PCR for SNP DNA sequencing was performed as described above using only the ASBTYR-F3 and ASBTYR-R3 primers. PCR products of the expected size were purified, sequenced and analyzed as described previously.

\section{Results}

In the studied herd, some of the cows were initially inseminated with semen imported from Bulgaria (from bull I-1 or II-2). According to the records, despite the fact that these two bulls were from the same Bulgarian stud, they were not related, at least up to two generations, but both grandfathers came from India, indicating a small chance of a previous relationship between them. Unfortunately, we have no information concerning the occurrence of albinism in this Bulgarian stud. During a 12 -year period, $1.6 \%(16 / 970)$ of the calves produced were born with albinism. The pedigree of the calves with albinism is presented in Figure 1. With the exception of X-257, which shared kinship with only one of the Bulgarian sires (I-1), all of the albino animals born into the herd shared kinship with both of the imported sires (I-1 and II-2) whose imported semen was used on the farm. The calculated frequency for the recessive allele was 0.0552 and the frequency of albinism in the herd was 16/970. Considering the active sires in 1996 as the founders of the herd, the mean consanguinity coefficient was $6.01 \%$ for the 84 animals born in 2009 . Among the albino animals, the consanguinity was $14.9 \%$, and only two of the albino animals showed no consanguinity (III-110 and X-257). The results of the segregation analysis showed that the assessed genealogical data agree with the hypothesis of autosomal recessive inheritance. When the numbers of albino offspring from sires considered unequivocally heterozygous mated with their own daughters or with daughters from heterozygous sires were compared using segregation analysis, we obtained a value of $12 / 73$, indicating no significant difference ( $>0.11$ ) from the expected value (9.1/73), even ignoring the possibility that the cows could have received the recessive allele from their mothers.

In the animals with albinism, the skin and the stratum corneum of the horns (Figure 2) and hooves were white, and the mucosa appeared pink. In the periocular region, an absence of pigmentation was observed in the eyelashes, conjunctiva and iris (Figure 3). The affected buffalo were able to avoid obstacles, but they manifested signs of photophobia by keeping their eyes only partially open, especially when exposed to sunlight.

The TYR mRNA sequence obtained from the wild-type buffalo was 1,958 base pairs (bp) in length (accession number JN_887462), including $39 \mathrm{bp}$ in the 5'untranslated region (UTR) and $326 \mathrm{bp}$ in the 3'-UTR. The open reading frame of the TYR sequence was 1,593 


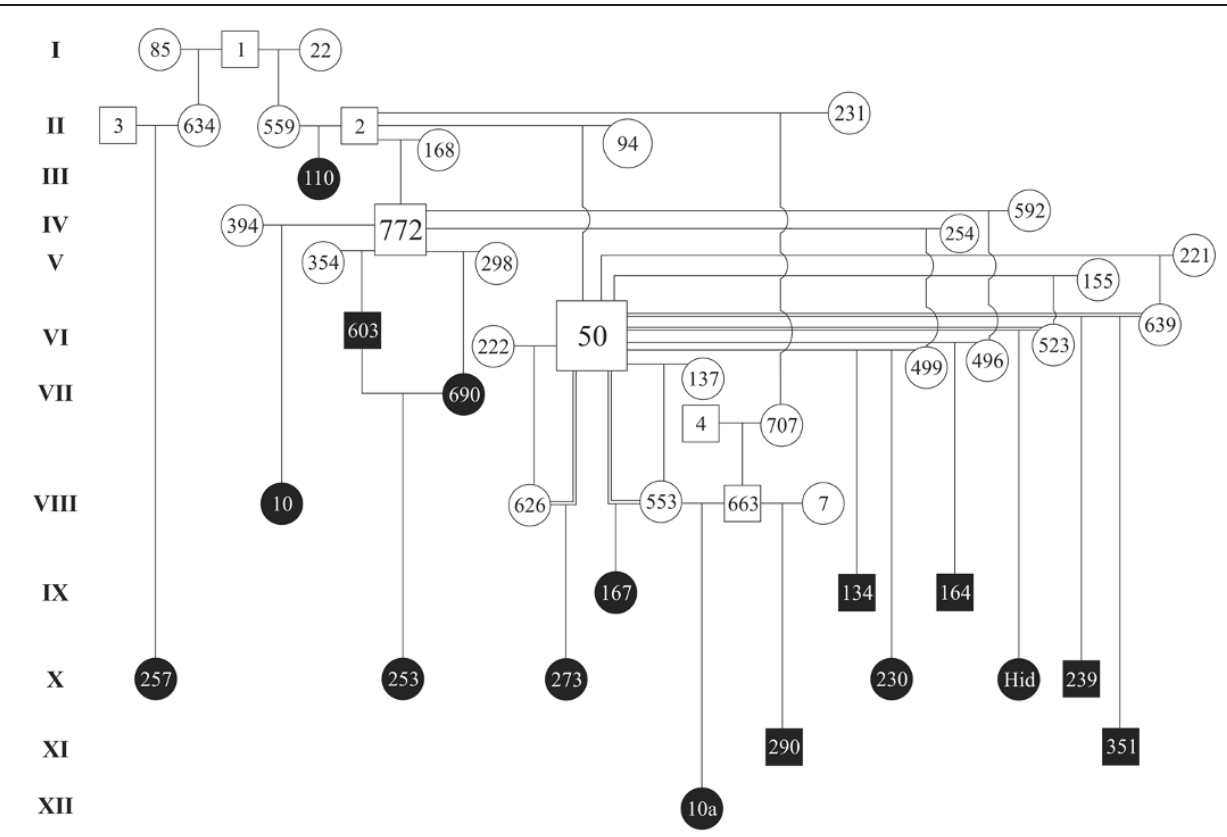

Figure 1 Pedigree of the albino buffalo herd. Black graphics represent the affected individuals.

bp long, and the corresponding peptide sequence consisted of 530 amino acids.

In comparisons of the buffalo TYR coding sequence with the TYR coding sequences from seven other mammalian species, we observed that the length did not vary, except compared to humans (one fewer amino acid) and mice (three additional amino acids). The TYR coding sequence of the wild-type buffalo shared a greater identity with the cattle (98\%) and sheep (97\%) sequences than with other mammalian TYR sequences deposited in GenBank $^{\mathrm{TM}}$.

The TYR gene sequence obtained for the OCA buffalo was deposited in GenBank ${ }^{\mathrm{TM}}$ (JN_887463). The sequence was then analyzed for polymorphisms between the OCA and wild-type buffalo. Comparison of the TYR coding regions in the OCA buffalo revealed a singlebase substitution at nucleotide 1,431 (G to A), which causes the conversion of a tryptophan $\left(\mathrm{TGG}_{477}\right)$ into a

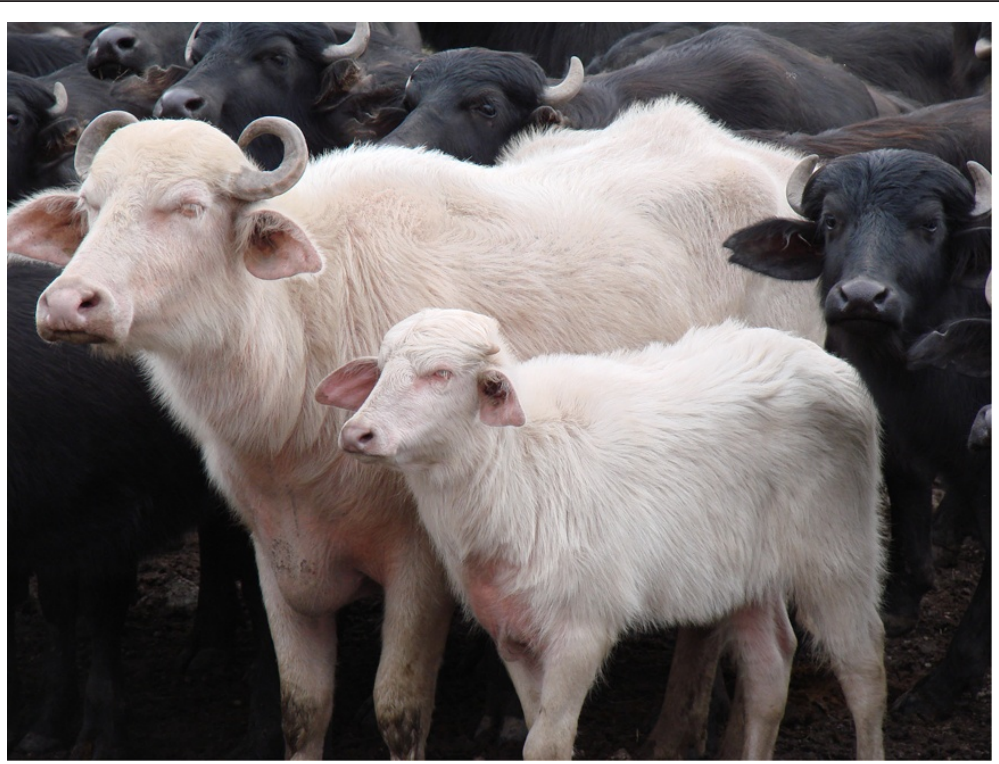

Figure 2 An albino dam and her albino calf (with photophobia) are shown among normal buffalo. 


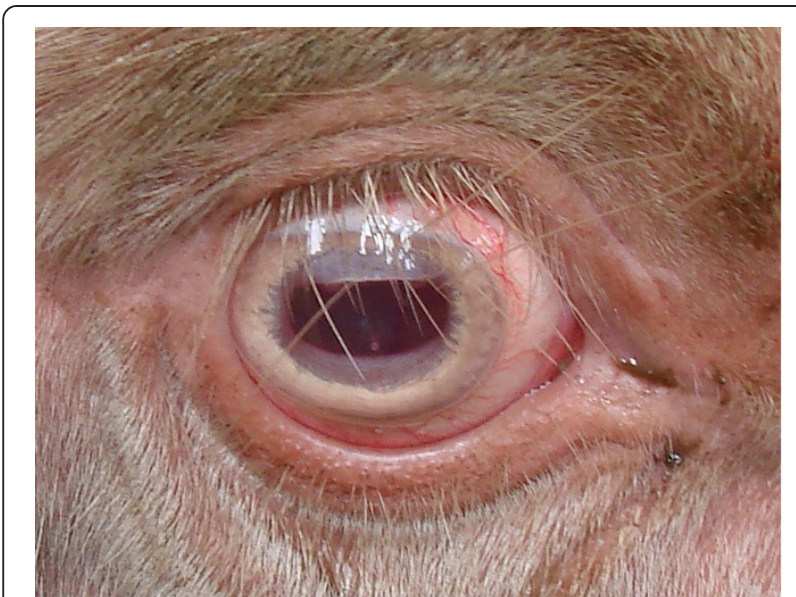

Figure 3 Periocular region in an albino buffalo with non-pigmented eyelashes, conjunctiva, and iris.

stop codon $\left(\mathrm{TGA}_{477}\right)$. This premature stop codon produces a truncated TYR protein with 53 fewer amino acids than the wild-type TYR protein.

The SNP sequence responsible for OCA in the buffalo was confirmed by PCR using the primers ASBTYR-F3 and ASBTYR-R3. The wild-type, heterozygote and albino sequences obtained in this study were assembled, and the resulting chromatogram is shown in Figure 4.

\section{Discussion}

Albinism was diagnosed in 16 buffalo over a 12-year period. The affected animals exhibited the characteristic phenotype of the disease: a white coat, non-pigmented skin and eyes, and pink mucosa [6,7]. In a previous experiment evaluating another recessive trait [21], some of the sires in the studied herd, including VI-50, were mated several times with their daughters and nieces. This contributed to the increased frequency of albinism among the herd (16/970) compared with the expected frequency if mating were randomly distributed (3/970), considering the expected allelic frequency. This breeding program also contributed to the increase of consanguinity in the herd. The results from the segregation analysis suggest that the recessive allele could have been introduced by the two imported sires. Consanguinity also contributed to other hereditary diseases observed in this herd, including hydranencephaly and cerebellar hypoplasia [21], acantholytic mechanobullous dermatosis [22], and arthrogryposis [23].

Decreased pigmentation in the iris and the retina leads to a diminished ability to absorb light. Light reflects off of normal blood vessels in the back of the eye through the pale iris, resulting in the red eye color found in the studied buffalo and in other species with albinism $[6,24]$. The photophobia observed in the albino buffalo is the result of insufficient or absent iris pigmentation, which causes increased light-sensitivity and discomfort in the animals when exposed to bright light [24].

Molecular abnormalities in the TYR gene that are responsible for OCA have been described in American mink [3], rabbits [4], chickens [5], cattle [6], whales [8], mice [25], rats [26], cats $[7,27,28]$, and ferrets [29]. In addition, approximately 200 TYR mutations have been described in humans (http://albinismdb.med.umn.edu/) [30]. Therefore, TYR was the first candidate gene to be tested in OCA buffalo, and the results of this study

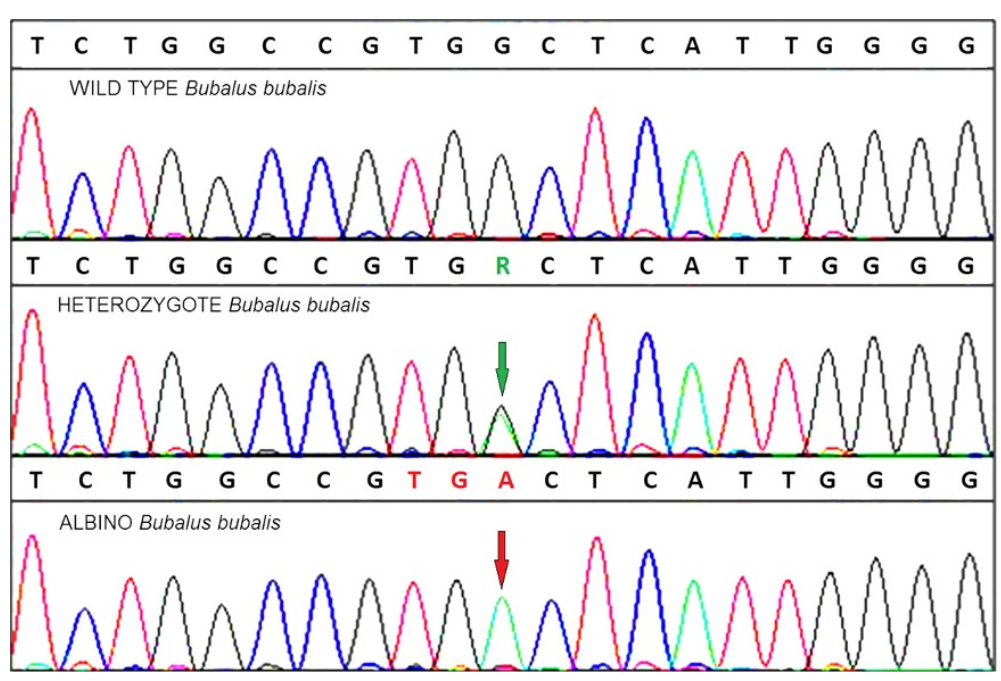

Figure $4 \mathrm{~A}$ partial chromatogram obtained from the assembly of tyrosinase sequences from wild-type, heterozygote and albino buffalo. The normal $G$ at the 11th nucleotide position shown in the picture was observed in the wild-type TYR sequence. A double peak (R: G/A) was observed in the heterozygote sequence (green arrow), and a point mutation ( $G$ to $A$ ) forming a premature stop codon (TGA) was observed in the albino sequence (red arrow). 
confirmed that TYR was also affected in these animals. However, the mutation reported in this study differed from all of the mutations described in other species.

A frameshift mutation generating a premature stop codon $\left(\mathrm{TGA}_{491}\right)$ resulting in a truncated TYR protein that is shortened by 21 amino acids has been reported in humans [31]. This mutation is found in the putative transmembrane region in exon 5 of the TYR gene (between nucleotides 1,420 and 1,500) and results in the elimination of the carboxy-terminal portion. In buffalo, the detected mutation also occurs in the putative transmembrane region in exon 5 of the TYR gene (nucleotide 1,431 ), generating a premature stop codon, and as in humans, the carboxy-terminal portion is also eliminated. This region contains a short amino acid sequence (serine-histidine-leucine) that acts as a targeting signal for the transport of several peroxisomal enzymes into peroxisomes [31,32].

The premature stop codon eliminates the targeting signal in humans [31] and most likely has the same effect in buffalo, thereby compromising the insertion and transport of the protein within the melanosome (considered to be modified peroxisomes) membrane and inactivating the tyrosinase enzyme. Nonsense-mediated mRNA decay (NMD) is a quality control mechanism that detects and degrades mRNAs containing premature termination codons. If translated, these mRNAs can produce truncated proteins with dominant-negative or deleterious gain-of-function activities [33,34]. This mechanism has implications for human diseases $[35,36]$ and has also been associated with a mutation resulting in a frameshift and a premature stop codon (exon 1) in the chicken sex-linked allele that causes imperfect albinism [37]. In the albino buffalo, the results of the RNA sequence evaluation indicate that this mechanism is most likely ineffective, as mRNAs with nonsense mutations in the final exon escape NMD because there is no intron downstream of the premature stop codon $[34,38-40]$.

\section{Conclusion}

In buffalo, albinism is an autosomal recessive disease. The detected premature stop codon $(\mathrm{G} 1431 \mathrm{~A})$ produces an inactive protein, which is responsible for the OCA buffalo phenotype.

\section{Competing interests}

The authors declare that there are no conflicts of interest, finance or relationships with other people or organizations that could inappropriately influence their work.

\section{Acknowledgements}

Funding for part of this work was provided by the Brazilian Research Council (CNPq 304920/2009-6).

\section{Author details}

${ }^{1}$ Brazilian Agricultural Research Corporation, Embrapa, Pelotas, Rio Grande do Sul 96.001-970, Brazil. ² Veterinary Hospital, Federal University of Campina Grande, Patos, Paraíba 58700-000, Brazil. 'aboratory of Molecular Biology of Department of Veterinary Clinical Science / College of Veterinary Medicine and Animal Science, Univ Estadual Paulista (Unesp), Botucatu, Sao Paulo 18618-970, Brazil. ${ }^{4}$ Laboratory of Molecular Biology of Department of Veterinary Clinical Science / College of Veterinary Medicine and Animal Science, Univ Estadual Paulista (Unesp), Botucatu, Sao Paulo 18618-970, Brazil. ${ }^{5}$ Departamento de Zootecnia / Faculdade de Ciências Agrárias e Veterinárias, Univ Estadual Paulista (Unesp), Jaboticabal, Sao Paulo 14884-900, Brazil. ${ }^{6}$ Veterinary Hospital, Federal University of Campina Grande, Patos, Paraíba 58700-000, Brazil. `Veterinary Diagnostic Laboratory, Federal University of Pelotas, Pelotas, Rio Grande do Sul 96010-900, Brazil.

\section{Authors' contributions}

ASB, FRC and ALS designed the study. MCFD and ALS performed the clinical examination and studied the albino buffalo herd. GMX and JPOF performed the molecular study. HNO performed the segregation analyses. All authors reviewed the literature, prepared the manuscript, and approved the final manuscript.

\section{Authors' information}

MCFD is from the Brazilian Agricultural Research Corporation - Embrapa, Pelotas, Brazil. GXM and FRC are from the Veterinary Hospital of the Federal University of Campina Grande, Patos, Brazil. JPOF and ASB are from the Laboratory of Molecular Biology of the Department of Veterinary Clinical Science / College of Veterinary Medicine and Animal Science, Univ. Estadual Paulista (Unesp), Botucatu, Brazil. HNO is from the Departamento de Zootecnia / Faculdade de Ciências Agrárias e Veterinárias, Univ Estadual Paulista (Unesp), Jaboticabal, Brazil. ALS is from the Veterinary Diagnostic Laboratory of the Federal University of Pelotas, Pelotas, Brazil.

Received: 12 January 2012 Accepted: 20 July 2012

Published: 20 July 2012

\section{References}

1. Lerner AB, Fitzpatrick TB, Calkins E, Summerson WH: Mammalian tyrosinase preparation and properties. J Biol Chem 1948, 3:185-195.

2. Oetting WS: The tyrosinase gene and oculocutaneous albinism type 1 (OCA1) a model for understanding the molecular biology of melanin formation. Pigment Cell Res 2000, 13:320-325.

3. Anistoroaei R, Fredholm M, Christensen K, Leeb T: Albinism in the American mink (Neovison vison) is associated with a tyrosinase nonsense mutation. Anim Genet 2008, 39:645-648.

4. Aigner B, Besenfelder U, Müller M, Brem G: Tyrosinase gene variants in different rabbit strains. Mamm Genome 2000, 11:700-702.

5. Tobita-Teramoto T, Jang GY, Kino K, Salter DW, Brumbaugh J, Akiyama T: Autosomal albino chicken mutation ( $\mathrm{ca} / \mathrm{ca}$ ) deletes hexanucleotide (-delta GACTGG817) at a copper-binding site of the tyrosinase gene. Poult Sci 2000, 79:46-50.

6. Schmutz SM, Berryere TG, Ciobanu DC, Mileham AJ, Schmidtz BH, Fredholm M: A form of albinism in cattle is caused by a tyrosinase frameshift mutation. Mamm Genome 2004, 15:62-67.

7. Imes DL, Geary LA, Grahn RA, Lyons LA: Albinism in the domestic cat (Felis catus) is associated with a tyrosinase (TYR) mutations. Anim Genet 2006, 37:175-178.

8. Polanowski AM, Robinson-Laverick SM, Paton D, Jarman SN: Variation in the tyrosinase gene associated with a white humpback whale (Megaptera novaeangliae). J Hered 2012, 103:130-133.

9. Manga P, Kromberg JGR, Box NF, Sturm RA, Jenkins T, Ramsay M: Rufous oculocutaneous albinism in Southern African blacks is caused by mutations in the TYRP1 gene. Am J Hum Genet 1997, 61:1095-1101.

10. Oetting WS, Garrett SS, Brott M, King RA: P gene mutations associated with oculocutaneous albinism type II (OCA2). Hum Mutat 2005, 25:323.

11. Lu H, Li L, Watson ER, Williams RW, Geisert EE, Jablonski MM, Lu L: Complex interactions of Tyrp1 in the eye. Mol Vis 2011, 17:2455-2468.

12. Schnur RE, Gao M, Wick PA, Keller M, Benke PJ, Edwards MJ, Grix AW, Hockey A, Jung JH, Kidd KK, Kistenmacher M, Levin AV, Lewis RA, 
Musarella MA, Nowakowski RW, Orlow SJ, Pagon RS, Pillers DA, Punnett MHH, Quinn GE, Kamer T, Wagstaff J, Weleber RG: OA1 mutations and deletions in X-linked ocular albinism. Am J Hum Genet 1998, 62:800-809.

13. Barbosa MDFS, Barrat FJ, Tchernev VT, Nguyen QA, Mishra VS, Colman SD, Pastural E, Dufourcq-Lagelouse R, Fischer A, Holcombe RF, Wallace MR, Brandt SJ, de Saint Basile G, Kingsmore S: Identification of mutations in two major mRNA isoforms of the Chediak-Higashi syndrome gene in human and mouse. Hum Mol Genet 1997, 6:1091-1098.

14. Li W, He M, Zhou H, Bourne JW, Liang P: Mutational data integration in gene-oriented files of the Hermansky-Pudlak syndrome database. Hum Mutat 2006, 27:402-407.

15. Kunieda T, Nakagiri M, Takami M, Ide H, Ogawa H: Cloning of bovine LYST gene and identification of a missense mutation associated with Chediak-Higashi syndrome of cattle. Mamm Genome 1999, 10:1146-1149.

16. Coban O, Yildiz A: Albinism in an anatolian buffalo calf. J Appl Anim Res 2005, 27:61-62.

17. Marcolongo-Pereira C, Schild AL, Soares MP, Vargas SF Jr, Riet-Correa F: Congenital defects in ruminants in southern Brazil. Pesq Vet Bras 2010, 30:816-826.

18. Levine CO: Albino water buffaloes. J Hered 1925, 16:66.

19. Kerr RJ, Kinghorn BP: An efficient algorithm for segregation analysis in large populations. J Anim Breed Genet 1996, 113:457-469.

20. Meuwissen THE, Luo Z: Computing inbreeding coefficients in large populations. Genet Sel Evol 1992, 24:305-313.

21. Schild AL, Fiss L, Damé MC, Uzal FA, Soares MP, Schuch LFD, Riet-Correa F: Congenital hydranencephaly and cerebellar hypoplasia in water buffalo in Southern Brasil. J Vet Diagn Invest 2011, 23:603-609.

22. Riet-Correa F, Barros SS, Damé MC, Peixoto PV: Hereditary suprabasilar acantholytic mechanobullous dermatosis in buffaloes (Bubalus bubalis). Vet Pathol 1994, 31:450-454.

23. Schild AL, Soares MP, Damé MC, Portiansky E, Riet-Correa F: Arthrogryposis in Murrah buffaloes in southern Brazil. Pesq Vet Bras 2003, 23:13-16.

24. Tomita Y, Suzuki T: Genetics of pigmentary disorders. Am J Med Genet C Semin Med Genet 2004, 131C:75-81.

25. Halaban R, Svedine S, Cheng E, Smicun Y, Aron R, Hebert DN: Endoplasmic reticulum retention is a common defect associated with tyrosinasenegative albinism. PNAS 2000, 97:5889-5894.

26. Blaszczyk WM, Arning L, Hoffmann KP, Epplen JT: A tyrosinase missense mutation causes albinism in the Wistar rat. Pigment Cell Res 2005, 18:144-145.

27. Lyons LA, Imes DL, Rah HC, Grahn RA: Tyrosinase mutations associated with Siamese and Burmese patterns in the domestic cat (Felis catus). Anim Genet 2005, 36:119-126.

28. Schmidt-Küntzel A, Eizirik E, O'Brien SJ, Menotti-Raymond M: Tyrosinase and Tyrosinase Related Protein I alleles specify domestic cat coat color phenotypes of the albino and brown loci. J Hered 2005, 96:289-301.

29. Blaszczyk WM, Distler C, Dekomien G, Arning L, Hoffmann KP, Epplen JT: Identification of a tyrosinase (TYR) exon 4 deletion in albino ferrets (Mustela putorius furo). Anim Genet 2007, 38:421-423.

30. Rooryck C, Morice-Picard F, Elçioglu NH, Lacombe D, Taieb A, Arveiler B: Molecular diagnosis of oculocutaneous albinism: new mutations in the OCA1-4 genes and practical aspects. Pigment Cell Melanoma Res 2008, 21:583-587.

31. Chintamaneni CD, Halaban R, Kobayashi Y, Witkop CJ, Kwon BS: A single base insertion in the putative transmembrane domain of the tyrosinase gene as a cause for tyrosinase-negative oculocutaneous albinism. Proc Natl Acad Sci USA 1991, 88:5272-5276.

32. Gould SJ, Keller GA, Subramani S: Identification of Peroxisomal Targeting Signals Located at the Carboxy Terminus of Four Peroxisomal Proteins. J Cell Biol 1988, 107:879-905.

33. Chang YF, Imam JS, Wilkinson MF: The nonsense-mediated decay RNA surveillance pathway. Annu Rev Biochem 2007, 76:51-74.

34. Zetoune $A B$, Fontanière $S$, Magnin $D$, Anczuków $O$, Buisson $M$, Zhang $C X$, Mazoyer S: Comparison of nonsense-mediated mRNA decay efficiency in various murine tissues. BMC Genet 2008, 9:83.

35. Frischmeyer PA, Dietz HC: Nonsense-mediated mRNA decay in health and disease. Hum Mol Genet 1999, 8:1893-1900.

36. Thein SL: Genetic insights into the clinical diversity of beta thalassaemia. Br J Haematol 2004, 124:264-274.
37. Gunnarsson $U$, Hellström AR, Tixier-Boichard M, Minvielle F, Bed'hom B, Ito $S$, Jensen P, Rattink A, Vereijken A, Andersson L: Mutations in SLC45A2 cause plumage color variation in chicken and Japanese quail. Genetics 2007, 175:867-877.

38. Perrin-Vidoz L, Sinilnikova OM, Stoppa-Lyonnet D, Lenoir GM, Mazoyer S: The nonsense-mediated mRNA decay pathway triggers degradation of most BRCA1 mRNAs bearing premature termination codons. Hum Mol Genet 2002, 11:2805-2814.

39. Maquat LE: Nonsense-mediated mRNA decay in mammals. J Cell Sci 2005, 118:1773-1776.

40. Khajavi M, Inoue K, Lupski JR: Nonsense-mediated mRNA decay modulates clinical outcome of genetic disease. Eur J Hum Genet 2006, 14:1074-1081.

\section{doi:10.1186/1471-2156-13-62}

Cite this article as: Damé et al:: A nonsense mutation in the tyrosinase gene causes albinism in water buffalo. BMC Genetics 2012 13:62.

\section{Submit your next manuscript to BioMed Central and take full advantage of:}

- Convenient online submission

- Thorough peer review

- No space constraints or color figure charges

- Immediate publication on acceptance

- Inclusion in PubMed, CAS, Scopus and Google Scholar

- Research which is freely available for redistribution

Submit your manuscript at www.biomedcentral.com/submit
() Biomed Central 